\begin{tabular}{c|c|c|}
\hline \hline & International Journal of Current Research in \\
\hline & Biosciences and Plant Biology \\
\hline EXCELLENT \\
PUBLISHERS
\end{tabular}

\title{
Contemplating Macrotyloma uniflorum in traditional snake envenomation management practices through analysis on various solvents by a scheme of spectroscopic, phytochemical and chromatographical analysis
}

\author{
Haritha Venugopal', K. G. Sasikumar², R. Prathapachandran3 and M. Anoop ${ }^{\text {1* }}$ \\ 1,3K. V. M. College of Science \& Technology, Kokkothamangalam PO, Cherthala- 688527, Kerala, India \\ ${ }^{2}$ Shanthinikethan, Pattanakad PO, Cherthala, Kerala, India \\ *Corresponding author; e-mail: mailmeanp86@gmail.com; +91-95675-20201.
}

\begin{tabular}{ll}
\hline Article Info & ABSTRACT \\
\hline $\begin{array}{l}\text { Date of Acceptance: } \\
\text { 18 April 2020 }\end{array}$ & $\begin{array}{l}\text { The idea of extrapolating the active principles in snake envenomation research in } \\
\text { Macrotyloma uniflorum is presented in this work on a preliminary analysis through } \\
\text { spectroscopic, chromatographic and phytochemical analysis. Similarity in the Rf values of }\end{array}$ \\
$\begin{array}{l}\text { Date of Publication: } \\
\text { o6 May 2020 }\end{array}$ & $\begin{array}{l}\text { o.9 ranges clearly indicated the presence of a common component .The UV-VIS } \\
\text { spectroscopic analysis have indicated the presence of unique peaks in 200-320 ranges } \\
\text { which predicted the presence of terpenoid compounds as it was discussed through the } \\
\text { presence of chromophores. The phytochemical analyses have confirmed the presence of } \\
\text { Keywords }\end{array}$ \\
$\begin{array}{l}\text { terpenoid through the presence of a brown color ring. The preliminary analysis floors a } \\
\text { base for the future drug formulation extending through the strategy of structural } \\
\text { Chromatography } \\
\text { Envenomation }\end{array}$ & $\begin{array}{l}\text { interpretation with NMR and mass spectrometer assays. With the climatic change and } \\
\text { poor waste management there occurs an increasing overlap between humans and } \\
\text { poisonous snakes. The risk factors are assessed and which leads to the formulation of } \\
\text { Spectroscopy } \\
\text { novel drug therapeutics. The work presents novel strategies in snake envenomation } \\
\text { research through a systems approach of research with Macrotyloma uniflorum alone and } \\
\text { in combination and was found to be effective in traditional snake envenomation practices. }\end{array}$ \\
&
\end{tabular}

\section{Introduction}

Most of the plants we see around us in our day today life have their own medicinal properties due to the presence of certain special compounds called secondary metabolites or in other words the presence of these special secondary metabolites gives certain plants their medicinal properties. These secondary metabolites are organic compounds which do not directly involve in the growth of the plants. Usually these secondary metabolites act as a defense mechanism for the self protection of the plants that is, they could act as an insecticide or pesticide in order to protect themselves and humans make use of these special components produced by plants for making natural insecticide, pesticide herbicide etc.

A wide variety of plants and their active principles have been evaluated for pharmacological properties (Gupta and Peshin, 2012). The plants used in experiments were Macrotyloma uniflorum have medicinal properties and in Ayurveda and was being used as part of different medicinal combination over several years. Macrotyloma uniflorum was considered as the most extensive 
crop grown in south India, the maximum in Andhra Pradesh, Karnataka and Tamil Nadu (Parvathiraj et al., 2015). These medicinal properties are due to the presence of those special components in it.

Secondary metabolites can be simply classified into three main groups: terpenes (such as cardiac glycosides, sterols, and carotenoids), phenolics (such as flavonoids, coumarins, tannins, and lignin) and nitrogen containing compounds (such as alkaloids and glucisinolates) (Agostini-Costa et al., 2012). The secondary metabolites are considered as the bioactive components and were elucidated with phytochemical analysis. The present study aims in extrapolating the active principles in Macrotyloma uniflorum contemplating the idea of traditional snake envenomation practice.

\section{Materials and methods}

\section{Collection of samples}

Seeds of Macrotyloma uniflorum, were collected from traditional Ayurvedic medical shop at Alappuzha, Kerala. The plant was identified at biotechnology department of KVM College of Science and Technology, Kokothamangalam, Cherthala. The sample collected and was powdered finely and dried under direct sunlight for 3 days and was stored in dry conditions.

\section{Cold extraction}

2.5g of the seed powder of Macrotyloma uniflorum were macerated separately in petroleum ether, acetone, ethanol-acetone, chloroform, ethyl acetate, methanol and water for 24 hours in the increasing order of their polarity. The collected samples were evaporated and filtered using Whatman filter paper No. 1.

\section{Thin layer chromatography}

Thin layer chromatography is a technique used for the separation of non-volatile mixtures. Here we use this technique to separate different components of the extracts. The solvent system used as the mobile phase is chloroform: ethyl acetate: acetic acid in the ratio 6.5:3.5:0.5. The plant extract in Petroleum ether, acetone, ethanol-acetone, chloroform, ethyl acetate, methanol and water were spotted on standard TLC silica plates and silica plates made of silica gel and calcium carbonate. The spots were analyzed and RF values were calculated. The spots were scrapped and the sample kept in refrigerator for FTIR and LCMS analysis.

\section{UV-Visible spectroscopy}

The Optical Density values were recorded with the help of an UV-Vis spectrophotometer in varying wavelengths from $280 \mathrm{~nm}-750 \mathrm{~nm}$ in $50 \mathrm{~nm}$ intervals for Macrotyloma uniflorum macerated in petroleum ether, acetone, ethanol-acetone, water and Optical Density values were recorded with the help of an UV-Vis spectrophotometer in varying wavelengths from $300 \mathrm{~nm}-500 \mathrm{~nm}$ in $30 \mathrm{~nm}$ intervals for Macrotyloma uniflorum macerated in chloroform, ethyl acetate, methanol and water.

\section{Phytochemical analysis}

Acetone extracts of Macrotyloma uniflorum were assayed for selected phytochemical tests like flavonoid, phenol, alkaloid and terpenoid tests under standard protocol to trace out the bioactive compounds which might be showing the potential in snake venom treatments (Rufus Auxila et al., 2013).

Test for flavonoids: Alkaline reagent test: $1 \mathrm{ml}$ of extract was mixed with $2 \mathrm{ml}$ of $2 \%$ of sodium hydroxide solution. An intense yellow colour were formed which turn colorless on addition of few drops dilute acid which indicate the presence of flavonoid.

Test for phenol: $1 \mathrm{ml}$ of extract was mixed with 2 $\mathrm{ml}$ of $2 \%$ ferric chloride solution. A Blue, Green or black coloration indicate the presence of phenols, tannins.

Test for alkaloids: $1 \mathrm{ml}$ of plant extract was mixed with $2 \mathrm{ml}$ of Wagner's reagent (dissolve $2 \mathrm{~g}$ of iodine and $6 \mathrm{~g}$ of potassium iodide in $100 \mathrm{ml}$ of water) and shaken well. Reddish brown precipitate indicates the presence of alkaloids.

Test for terpenoids: $0.1 \mathrm{ml}$ of plant extract was mixed with $0.5 \mathrm{ml}$ chloroform and $1.25 \mathrm{ml}$ of 
concentrated sulfuric acid were carefully added to form a layer. Presence of reddish brown color at the interface gives the positive result.

Terpenoid assay for different solvent extracts of Macrotyloma uniflorum: $0.5 \mathrm{ml}$ of plant extract was mixed with $2 \mathrm{ml}$ chloroform and $5 \mathrm{ml}$ of conc. $\mathrm{H}_{2} \mathrm{SO}_{4}$ carefully added to form a layer. Presence of reddish brown color at the interface gives the positive results. Terpenoid test was carried out for Macrotyloma uniflorum in petroleum ether, acetone, ethanol-acetone, chloroform, ethyl acetate, methanol and water.

\section{Results and discussion}

\section{Thin layer chromatography}

Thin layer chromatography of plant extract in seven different solvents was spotted on TLC plate and the RF values calculated are shown in Table 1.

\section{UV-Visible Spectroscopy}

The UV-Vis spectrophotometer presented maximum absorbance in aqueous extracts and minimum in petroleum ether. The maximum peak was found in $380 \mathrm{~nm}$ in aqueous extract $230-320$ $\mathrm{nm}$ in acetone. The UV-Vis absorbance different extracts are shown in Fig. 1 and Fig. 2.

Most of the unique peaks were distributed between $300 n m-500 n m$ for various solvent extracts as they have shown minimum absorption. This was further assessed in $30 \mathrm{~nm}$ intervals for Macrotyloma uniflorum in other solvents like chloroform, ethyl acetate, methanol and water. The maximum absorbance was for chloroform and water at 500 $\mathrm{nm}$. Petroleum ether extract showed a maximum peak at 200nm but was not showing any further activities upon higher peak ranges from 230 to 750 .

Table 1. RF values depicting different solvent extracts of Macrotyloma uniflorum.

\begin{tabular}{llllllll}
\hline $\begin{array}{l}\text { Solvents } \\
\text { used }\end{array}$ & $\begin{array}{l}\text { Petroleum } \\
\text { ether }\end{array}$ & Acetone & $\begin{array}{l}\text { Ethanol- } \\
\text { acetone }\end{array}$ & Chloroform & $\begin{array}{l}\text { Ethyl } \\
\text { acetate }\end{array}$ & Methanol & water \\
\hline RF value & 0.9 & 0.9 & 0.9 & 0.9 & 0.975 & 0.9574 & 0.9 \\
\hline
\end{tabular}

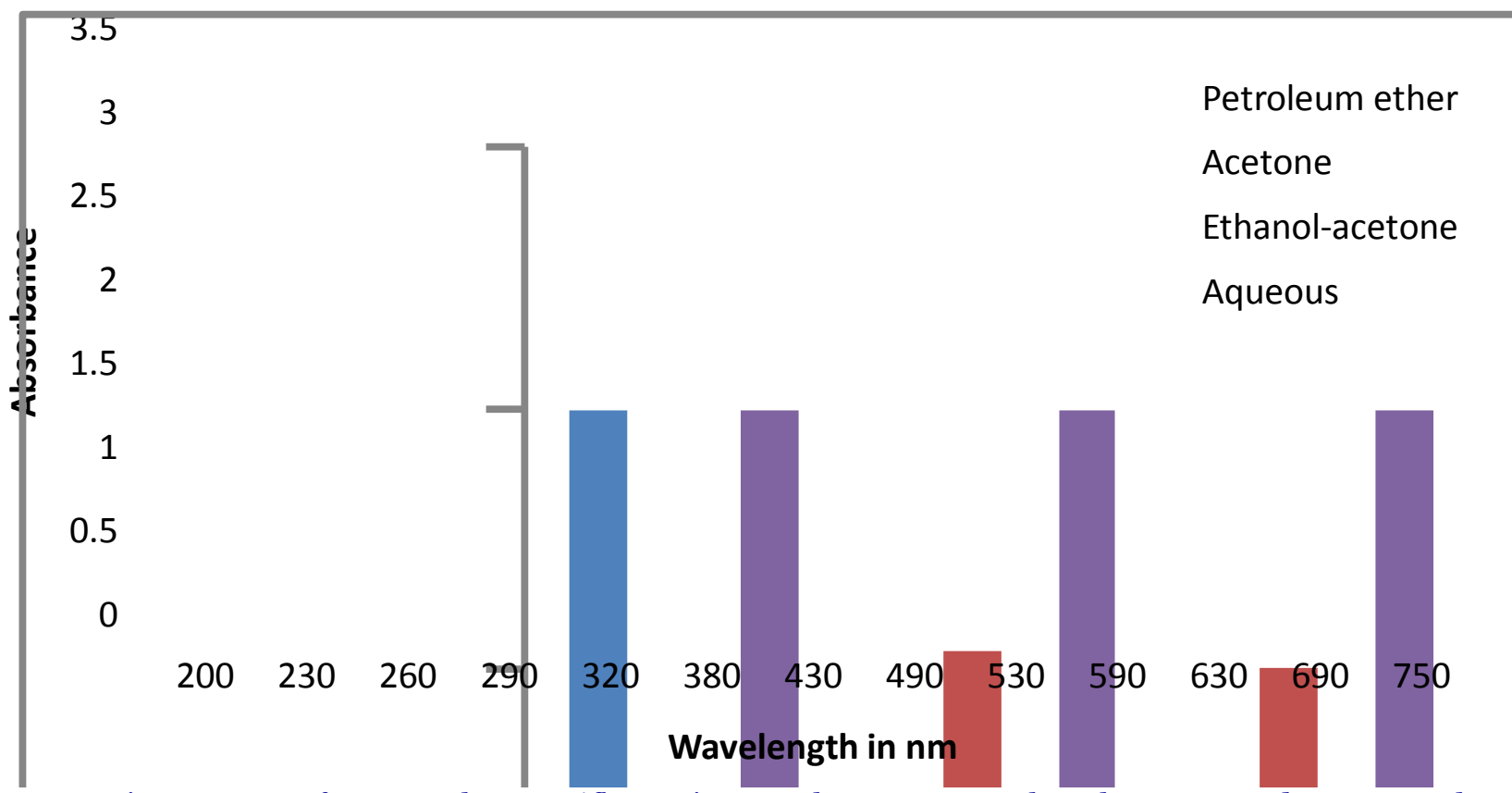

Fig. 1: UV-Vis spectrum of Macrotyloma uniflorum in Pet-ether, acetone, ethanol-acetone and aqueous solvents. 


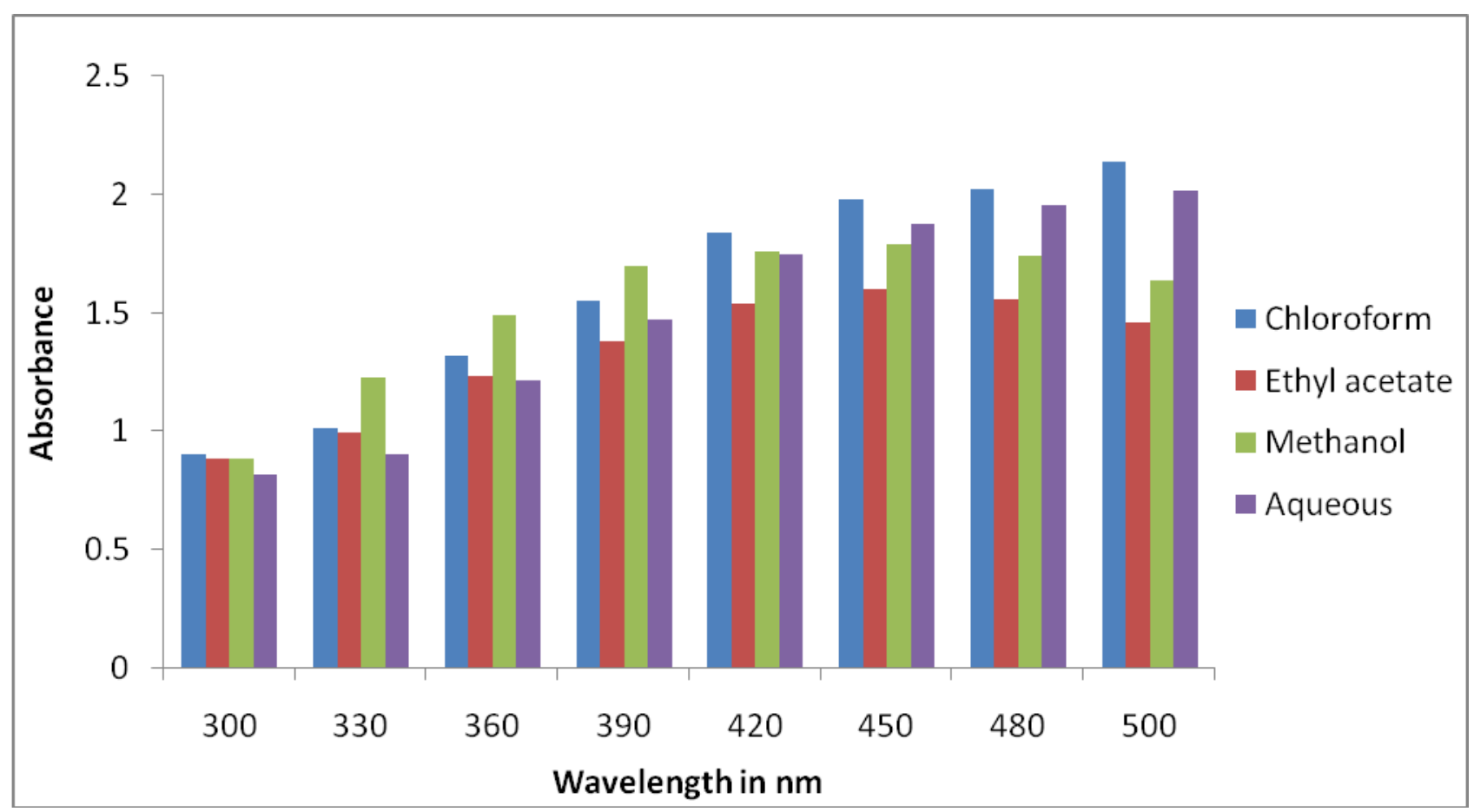

Fig. 2: UV-Vis spectrum of Macrotyloma uniflorum in chloroform, ethyl acetate, methanol and aqueous solvents.

\section{Phytochemical analysis}

Compared to highly polar water, low polar acetone showed remarkable activity in 200-320 $\mathrm{nm}$ wavelength ranges which facilitated a further analysis on acetone extract and the result is depicted as terpenoid positive for the acetone extract of Macrotyloma uniflorum (Table 2; Fig. 3). The acetone extract showed negative for flavonoid, phenolics and alkaloids test.

Table 2. Qualitative flavonoid, phenolics, alkaloid and terpenoid test for acetone extract of Macrotyloma uniflorum.

\begin{tabular}{lllll}
\hline Sample & Flavonoid & Phenolics & Alkaloid & Terpenoid \\
\hline Result & -ve & -ve & -ve & Slight reddish brown colour appeared \\
\hline
\end{tabular}

(a)

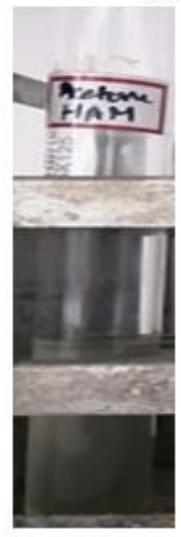

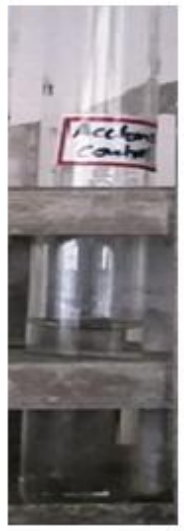

(b)

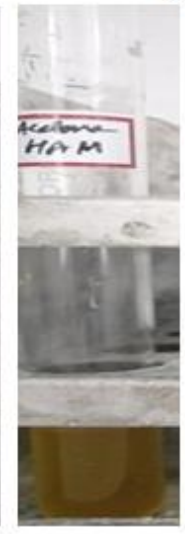

(c)

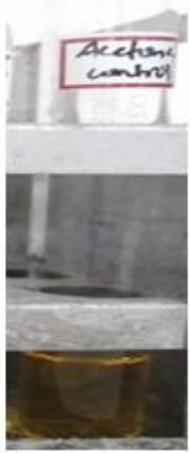

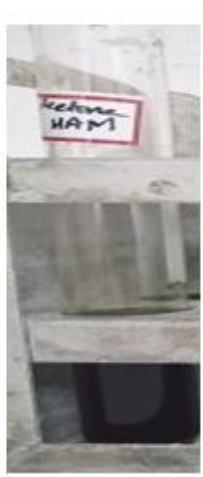

(d)

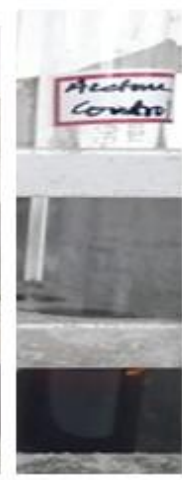

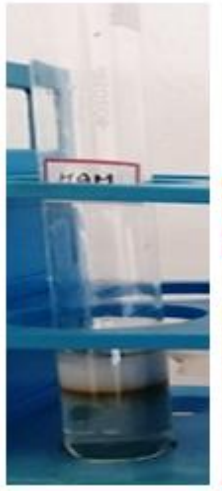

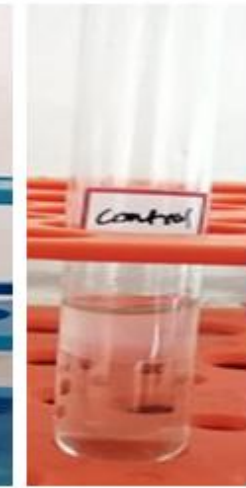

Fig. 3: Image depicting (a) Flavonoid, (b) Alkaloid, (c) Phenolics, (d) Terpenoid in acetone extract of Macrotyloma uniflorum. 


\section{Terpenoid test for different solvent extracts of Macrotyloma uniflorum}

The plant extract measuring $0.5 \mathrm{ml}$ was mixed with $2 \mathrm{ml}$ chloroform and $5 \mathrm{ml}$ of conc. $\mathrm{H}_{2} \mathrm{SO}_{4}$ carefully added to form a layer. Presence of reddish brown color at the interface gives the positive result as shown in Fig. 4 and Table 3.

Table 3. Qualitative terpenoid assay for different solvent extracts of Macrotyloma uniflorum.

\begin{tabular}{llllllll}
\hline Sample & $\begin{array}{l}\text { Pet } \\
\text { Ether }\end{array}$ & Acetone & $\begin{array}{l}\text { Eth- } \\
\text { Acetone }\end{array}$ & Chloroform & Ethyl-acetate & Methanol & Aqueous \\
\hline Result & + & $\begin{array}{l}\text { Slight reddish } \\
\text { brown colour } \\
\text { appeared }\end{array}$ & + & $\begin{array}{l}\text { Slight reddish } \\
\text { brown colour } \\
\text { appeared }\end{array}$ & $\begin{array}{l}\text { Very slight } \\
\text { reddish brown } \\
\text { colour appeared }\end{array}$ & $\begin{array}{l}\text { Slight reddish } \\
\text { brown colour } \\
\text { appeared }\end{array}$ & $\begin{array}{l}\text { Slight } \\
\text { reddish } \\
\text { brown colour } \\
\text { appeared }\end{array}$ \\
\hline
\end{tabular}

(a)

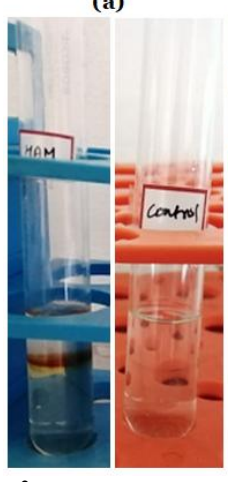

(b)

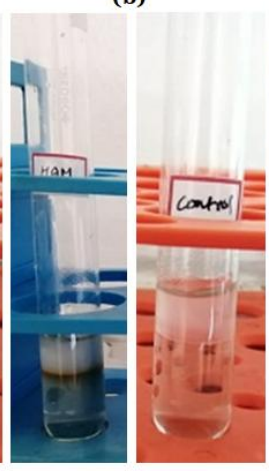

(c)

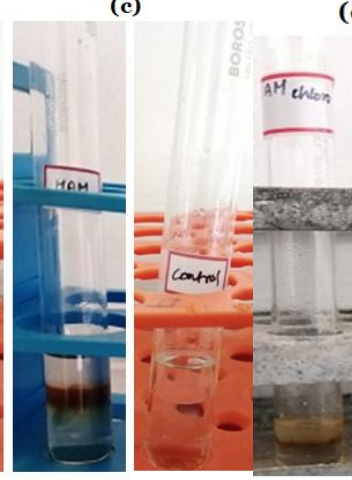

(d)

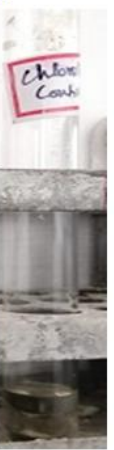

(e)

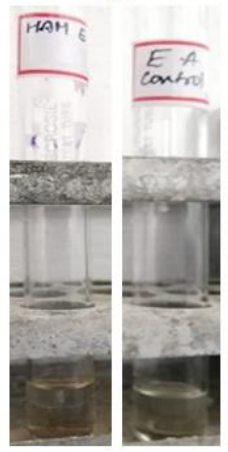

(f)

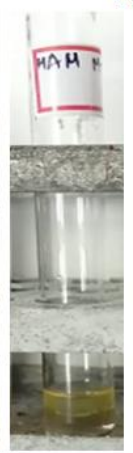

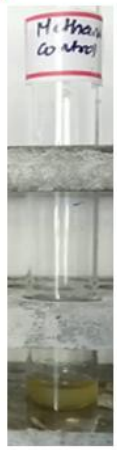

(g)

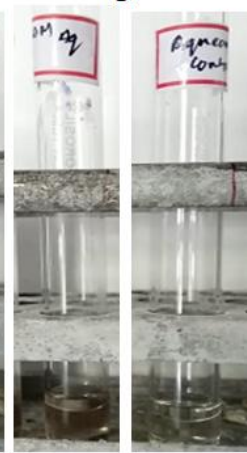

Fig. 4: Image depicting terpenoid results for (a) Petroleum ether, (b) Acetone, (c) Ethanol-acetone, (d) Chloroform, (e) Ethyl-acetate, (f) Methanol, and (g) Aqueous extracts of Macrotyloma uniflorum.

Snake bite deaths can be considered as a neglected tropical disease that kills nearly 100000 people in a year. Even those who survive may face health disabilities (Williams and Vijyapuri, 2019). Snake envenomation works has been constantly practiced by Macrotyloma uniflorum in single and in combination in traditional snake envenomation practices. The Plant sample presented TLC values of $0.9 \mathrm{RF}$ ranges for all the solvent extracts which were experimented (Table 1). The UV-Vis spectrometer values revealed the absorption maxima for aqueous extract at 250-750 wavelength ranges. The research work got highlighted when the acetone extract of Macrotyloma uniflorum has showed spectra range of 200-320 (Fig. 1). This predicted the presence of terpenoids as the functional group present in them are generally termed as chromophores and are ranged in between 200-350nm wavelength ranges. They may constitute oleifinic bonds and carbonyl bonds. Phytochemical analysis of Macrotyloma uniflorum has confirmed the prediction from UV-VIS spectrum analysis. Upon the analysis, acetone extract (Table 2) has presented the presence of terpenoids with slight reddish brown color upon qualitative analysis. Chloroform, methanol and aqueous extracts have revealed the same (Fig. 4). Ethanol-acetone solvent combination showed remarkable result with intensive coloration and has found to be a suitable solvent system for terpenoid content analysis from Macrotyloma uniflorum.

\section{Conclusion}

The antisnake venom usage may be limited by inadequate storage conditions and adverse drug reactions (Himmantrao and Pramodini, 2019). The work presented a preliminary assay on the nature of Macrotyloma uniflorum in snake envenomation research practices. The commonly known leguminous plant horse gram, plays a key role in plant defense response with its unique characteristics (Priya and Jayanthi, 2016). The 
plant has shown remarkable results when it was assayed for phytochemicals after a thorough evaluation through UV-VIS spectroscopy. Terpenoids, being the major class in photochemical revealed its presence effectively when searched with every solvent extracts. The active principles present in Macrotyloma uniflorum were enumerated as terpenoid class compounds which may trigger the evolution of new formulation of drugs that shows snake envenomation in future.

\section{Conflict of interest statement}

Authors declare that they have no conflict of interest.

\section{References}

Agostini-Costa, T. S., Vieira, R. F., Bizzo, H. R., Silveira, D., Gimenes, M. A., 2012. Secondary metabolites, chromatography and its applications, Sasikumar Dhanarasu, IntechOpen, DOI: 10.5772/35705. Available from: https://www.intechopen.com/books/ chromatography-and-its-applications/seconddary-metabolite

Gupta, Y. K., Peshin, S. S., 2012. Do herbal medicine has the potential for managing snake bite envenomation. Toxicol. Int. 19(2), 89-99.

Himmatrao, S. B., Pramodini, H. B., 2019. Snake bite -prevention and management in rural India settings. Lancet Glob. Health. 7(9), e1178.

Parvathiraj, P., Sudhakaran, M. R., Athinarayanan, G., Narayanan, K. R., 2015. Phytochemical analysis and antibacterial activity of seed extracts of Macrotyloma uniflorum (Horse Gram). Asia J. Appl. Microbiol. 2(1), 1-9.

Priya, C., Jayanthi, A., 2016. Antimicrobial and cytotoxic effects of Macrotyloma uniflorum extract. Int. J. Pharmacogn. Phytochem. Res. 8(8), 1334-1340.

Rufus Auxilia, L., Daniel, R. R., Shenbagarathai, R., 2013. Phytochemical analysis of seed extracts Macrotyloma uniflorum (Horse gram). Int. J. Curr. Res. 5(11), 3339-3342.

Williamns, H. F., Vajyapuri, S., 2019. The urgent need to develop novel strategies for the diagnosis and treatment of snake bites. Toxins. 11(6), 363 .

\section{How to cite this article:}

Haritha, V., Sasikumar, K. G., Prathapachandran, R., Anoop, M., 2020. Contemplating Macrotyloma uniflorum in traditional snake envenomation management practices through analysis on various solvents by a scheme of spectroscopic, phytochemical and chromatographical analysis. Int. J. Curr. Res. Biosci. Plant Biol. 7(5), 40-45. doi: https://doi.org/10.20546/ijcrbp.2020.705.006 